\title{
MONITORING OF ASSESSMENT, MOTIVATION AND STIMULATION PROCESSES OF PERSONNEL IN THE SYSTEM OF EFFECTIVE MANAGEMENT OF THE MACHINE-BUILDING ENTERPRISE
}

\author{
Levytska I., *Klymchuk A. \\ National University of Life and Environmental Sciences of Ukraine \\ Ukraine, 03041, Kyiv, Heroiv Oborony str., 11 \\ * State University Zhytomyr Polytechnic \\ Ukraine, 10005, Zhytomyr, Soniachna str., 103 \\ inna_levytska@ukr.net, alena_klumchyk@ukr.net \\ ORCID ID 0000-0002-5810-7527, 0000-0002-5246-8778
}

Key words:

monitoring, personnel, motivation and stimulation, assessment, productivity, labor activity.
The article is devoted to the research of actual problems of formation and use of assessment monitoring, motivation and stimulation of personnel of machine-building enterprises. In today's conditions, given the high dynamism of the development of competency characteristics of personnel, the enhancement of its professional and business qualities, which in practice do not always meet the requirements that are put forward to employees by managers as well as by the environment, it is necessary to create a rather qualitative system of the level of development of personal observation with the purpose of its effective use in the process of implementation of economic activity. This is precisely the task the monitoring of the motivation and stimulation processes of personnel is designed for, which creates additional opportunities to assess and bring the relationship between managers and subordinates to a higher level. The purpose of the article is to determine the basis of formation and effective use of the assessment monitoring, motivation and stimulation of personnel of the enterprise, which would be based on the systematic tracking of motivational needs of workers and their satisfaction by using appropriate incentive schemes for each employee, thus ensuring, in the long run, the effective work of the motivational mechanism.

Thus, the article outlines provisions, conclusions and recommendations aimed at solving a scientific problem in the development of assessment monitoring, motivation and stimulation of personnel, which includes a structured scheme of stages and a monitoring algorithm, as tools. The object of the research is the processes of formation and use of monitoring as the basis of effective evaluation, increase of motivation and stimulation of personnel of the machine-building enterprise. The theoretical and methodological basis of the article is the classical positions of economic theory, fundamental works of the domestic and foreign scientists and practitioners on personnel management, its assessment, motivation and stimulation. The use of a properly selected methodology for the formation and application of assessment monitoring, motivation and stimulation of machine-building enterprise personnel contributes to obtaining reliable and complete results of its activities and identifying problems that arise in the process of personnel management.

The results of our research lie in the formation of monitoring stages of evaluation, motivation and stimulation of personnel at the machine-building enterprise and its implementation algorithm with a final assessment of its results regarding the adoption of managerial decisions aimed at the effectiveness of personnel work, which will provide periodic assessment of staff motivation level, results of its work and effectiveness of the existing motivation system at the enterprise with the help of feedback channels, elimination of actual indicators from normative.

\section{МОНІТОРИНГ ПРОЦЕСІВ ОЦНКИ, МОТИВАЦЇ ТА СТИМУЛЮВАННЯ ПЕРСОНАЛУ В СИСТЕМІ ЕФЕКТИВНОГО УПРАВЛІННЯ МАШИНОБУДІВНИМ ПІДПРИЕМСТВОМ}

\author{
Левицька І.В., *Климчук А.О. \\ Національний університет біоресурсів та природокористування Украйни \\ Україна, 03041, м. Київ, вул. Героїв Оборони, 11 \\ *Державний університет «Житомирська політехніка» \\ Україна, 10005, м. Житомир, вул. Чуднівська, 103
}

Ключові слова:

моніторинг, персонал, мотивація та стимулювання, оцінка, продуктивність, трудова діяльність.
Стаття присвячена дослідженню актуальних проблем формування та використання моніторингу оцінки, мотивації та стимулювання персоналу машинобудівних підприємств. В умовах сьогодення зважаючи на високий динамізм розвитку компетентісних характеристик персоналу, підвищення його професійних та ділових якостей, які на практиці не завжди відповідають тим вимогам, які висувають до працівників як керівники, так i навколишнє середовище, необхідним $є$ створення досить якісної системи спостереження за рівнем розвитку персоналу з метою його ефективного використання в процесі 
здійснення господарської діяльності. Якраз це покликаний вирішити моніторинг процесів мотивації та стимулювання персоналу, який створює додаткові можливості оцінити та вивести відносини між керівниками та підлеглими на більш досконалий рівень. Метою статті $є$ визначення основ 3 формування та ефективного використання моніторингу оцінки, мотивації та стимулювання персоналу підприємства, який би базувався на систематичному відслідковуванні мотиваційних потреб працівників і міри їх задоволення за допомогою використання відповідних систем стимулювання щодо кожного працівника, таким чином забезпечуючи в перспективі ефективну роботу мотиваційного механізму.

Таким чином, у статті викладено положення, висновки та рекомендації, які спрямовані на вирішення наукової проблеми щодо розробки моніторингу оцінки, мотивації та стимулювання персоналу, який включає в якості інструментів розроблену структурну схему етапів та алгоритм моніторингу. Об'єктом дослідження є процеси формування та використання моніторингу як основи ефективної оцінки, підвищення мотивації та стимулювання персоналу машинобудівного підприємства. Теоретичним і методичним підгрунтям статті $\epsilon$ класичні положення економічної теорії, фундаментальні праці вітчизняних та зарубіжних вчених і практиків з питань управління персоналом, його оцінки, мотивації й стимулювання. Використання правильно підібраної методики формування та застосування моніторингу оцінки, мотивації та стимулювання персоналу машинобудівного підприємства сприяє отриманню достовірних і повних результатів його діяльності та визначенню проблем, які виникають в процесі управління персоналом.

Результати наших досліджень полягають у формуванні етапів моніторингу оцінки, мотивації й стимулювання персоналу на машинобудівному підприємстві та алгоритму його запровадження 3 кінцевою оцінкою його результатів щодо прийняття управлінських рішень, спрямованих на ефективність трудової діяльності персоналу, що забезпечить за каналами зворотного зв'язку періодичне оцінювання рівня вмотивованості персоналу, результатів його трудової діяльності та ефективність існуючої на підприємстві системи мотивації, здійснюючи усунення фактичних показників від нормативних.

\section{Statement of the problem}

The modern way to activate the workforce of the personnel and its efficient use by the enterprise is to study the level of motivation of personnel, factors of motivation and demotivators, as well as the development, on this basis, of an effective system of personnel stimulation, which will reverse the strategic objectives of the enterprise. In today's conditions, given the high dynamism of the development of competency characteristics of personnel, the increase of its professional and business qualities, which in practice do not always meet the requirements that are put forward to employees by managers as well as by the environment, it is necessary to create a rather qualitative system of the level of development of personal observation with the purpose of its effective use in the process of economic activity implementation. This is precisely the task the monitoring of motivation and stimulation processes of personnel is designed for, which creates additional opportunities to assess and bring the relationship between managers and subordinates to a higher level. In this aspect, apt is the statement concerning the occasional and rather superficial study of the needs, interests, motives and stimulants of the personnel in Ukraine, which leads to the efficiency decrease of existing at the enterprises systems of material and non-material motivation and stimulation (Kolot, 2006). Therefore, there is an urgent need of using assessment monitoring, motivation and stimulation of the machine-building enterprises personnel.

\section{Analysis of recent studies and publications}

The following well-known scientific works have been devoted to the problems of staff motivation scientists of the past and present, such as K. Aldefer, W. Vroom, F. Herzberg, D. McGregor, D. McClelland, A. Maslow, E. Mayo and others. The theoretical basis for the analysis of motivation of the personnel of the enterprises became scientific works of Russian scientists: V. Adamchuk, O. Vykhansky, B. Genkin, A. Zdravomyslov, A. Leontiev, V. Travin, L. Shakhovskaya and others. Among domestic scientists, a significant contribution to the development of the problem of motivation staff made V. Abramov, D. Goddess, V. Danyuk, O. Grishnova, G. Dmitrenko, M. Doronin, T. Zavinovska, M. Karlin, A. Kolot, O. Pushkar and others.

Modern scientific literature, presented by the works of leading scientists, scholars and management specialists, is characterized by the existence of a number of approaches as for the definition of the concept of "monitoring". The most widespread approach to the characterization of this term is its disclosure as "continuous monitoring of any process aimed at achieving a desired result or its compliance with the primary assumption - observation, assessment and prediction of the state of the environment associated with human activity "(Krysyn, 2007). At the same time regular monitoring is conducted to obtain results, determine effectiveness and efficiency of activities disclosed as measurement of the results (Parkhomchuk, 
2001). The essence of monitoring is also conditioned by both: regular collection and processing of information with the purpose of communicating information to the public, and may also be an instrument that includes feedback channels with the purpose of projects implemention, programs appraisal, strategies or policy abuses (Kniaz, 2006).

Effective formation and implementation of the monitoring system in the machine-building industry in conjunction with the refinement of its structural components, which are constantly interconnected and mutually complementary, are the basis for ensuring highly effective implementation of the functions, which are being explored in the process of enterprise management.

The Performance Appraisal Handbook (2010) streamlines the essence of monitoring to ensuring the effectiveness and timeliness of feedback channels, which will be implemented in the process of personnel assessment. The significance of such monitoring is to provide managers with opportunities to find out how well employees from other departments, shops, sections and other structural divisions of the enterprise are working, identifying aspects that require adjustments in order to make managerial decisions about achieving the planned results.

This is exactly the approach that the assesement monitoring, motivation and stimulation of personnel of a machine-building enterprise is based on the collection and processing of information aimed at making managerial decisions as for effective improvment of the competitiveness of employees at different levels of management. From our point of view, personnel assessment monitoring, motivation and stimulation should be one of the structural components of the AMMSEP, providing opportunities for regular monitoring of the cost expense as well as the results of employees' activities in different professional qualifications, receiving timely information on its changes, identification of actual issues, and, on this basis, the adoption of managerial decisions on personnel assessment, development and provision of an adequate level of their motivation and stimulation at the machinebuilding enterprise.

The main function of such an information system as monitoring is a regular observation, with keeping certain intervals, of work and personnel behavior, the dynamics of their changes, and the search for a correlation between the main parameters of the work results.

\section{Objectives of the article}

The objective of the article is to determine the basis for the formation and effective use of the assessment monitoring, motivation and stimulation of the enterprise personnel, which would be based on the systematic tracking of the motivational needs of employees and their satisfaction by using appropriate incentive systems for each employee, thus ensuring in the long run the effective operation of the assessment mechanism, motivation and stimulation of the personnel.

\section{The main material of the research}

Monitoring of motivation and stimulation processes is a system of constant observation and control over the state of labor activity with the purpose of operative diagnostic and dynamical assessment, and adoption of qualified management decisions in the interests of improving production efficiency.

At the level of enterprises, the work of stimulation and motivation services (separate specialists) is aimed at studying constantly changing needs, interests, value orientations of employees in the field of labor, motivations and stimulants of their work, motivational potential and the level of use at the labor process, the detection of changes in the structure of motives and stimulants, as well as forecasting of their development and influence on the performance results. The motivation processes monitoring and personnel stimulation must contribute to the identification of the most important values and influences on the work of certain employees with the purpose of achieving personal goals as well as goals of the enterprise.

Proceeding from this, monitoring of motivation and stimulation of personnel is defined as a process of implementation of regular allegations and observations, analysis of current ecoonomic, sociological and psychological information at the enterprise, assessment and forecasting of the level of motivation of personnel and existing at the enterprise systems of labor activity stimulation of workers and their impact on productivity with the purpose of forecasting the economic activity of the enterprise and prevention of probability of negative events and consequences occurrence, neutralization of their influence on the financial results of the enterprise and ensuring effective management of the machinebuilding enterprise and provision of effective machine building enterprise management (Penc, 2001).

Therefore, the use of processes of motivation and personnel stimulation makes it possible to evaluate and improve the existing system of personnel stimulation, aimed at activization of their work, revealing hidden possibilities and development of creative abilities, on the basis of which it is possible to adjust the directions and objectives of the enterprise management, which will positively influence the work of the PAMSM.

To maximize the effectiveness, we propose monitoring on a quarterly basis, which will allow us to get an assessment of the quarterly scheduled tasks. The monitoring of motivation and stimulation processes should be carried out by the professional staff of managers, specialists, employees, main and auxiliary personnel; by units, divisions and shops, departments and other subdivisions of the enterprise with the purpose of obtaining an assessment of the group level motivation and effectiveness of the group system of personnel stimulation of units, divisions and shops, departments, etc. 
Based on the above, among the main tasks of assessment monitoring, motivation and stimulation processes of machine-building enterprises personnel it is appropriate to highlight:

- systematic measurement and analysis of indicators of labor activity and motivation of personnel according to the professional composition and divisions of the enterprise;

- assessment of the existing systems of effectiveness and methods of personnel stimulation at the enterprise with a view to their further improvement;

- substantiation of new and improved systems of the personnel payment organization taking into account its professional structure;

- formation of an informational base concerning the level of motivation of the personnel and the efficiency of the existing system of stimulation of its work activity with the purpose of further use of statistical data aimed at effective formation and efficiency ensurance in the work of the PAMSM;

- formation of advisory measures aimed at increasing the efficiency of the stimulation system for the enterprise personnel in a variety of professional fields;

- improvement of existing methods of personnel stimulation at the enterprise and development of new, more qualitative ones.

Consequently, the main tasks assigned to monitoring should be to divided into two bitg groups: assessment and analysis of the personnel work, its competitiveness and level of motivation; research and development of measures aimed at improving the existing at the enterprise system of personnel stimulation.

In our opinion, the processes of motivation monitoring and stimulation of personnel of machine-building enterprises is an instrument which pursues the main goal - effective formation and ensurance of the effective use of AMMSEP, which will ensure effective management of the enterprise with the purpose of its further development.

Note that the formation of PAMSM is carried out in stages, based on the analysis of the indicators of labor activities of personnel and the existing at the enterprise system to stimulate it. As a part of these stages the degree of employee satisfaction with this system is also considered. Consequently, the essence of the assessment monitoring, motivation and stimulation of personnel is to first identify the existing motives and stimulants in a particular category of personnel, department, shop, division, etc., as well as their impact on the results of the current workforce.

According to M.P. Lukashevych sociological research (Lukashevych, 2004), in any labor collective it is possible to highlight the attitude to work by the following groups of workers:
1) an over-normative type of group, which consists of exclusively conscientious employees, whose share is about $5 \%$ of the total number of employees in the team;;

2) a normative type of group, which includes fairly diligent workers, the share of which is approximately $60 \%$;

3) a sub-normative type of group, which includes not fully diligent employees, whose share is $30 \%$;

4) a non-normative type of group which consists of unscrupulous workers, whose share is about $5 \%$.

Therefore, the task of monitoring is to identify exactly how existing at the enterprise incentive systems and enhancement of staff motivation to work activities affect the productivity of workers and the effectiveness of management staff.

Note that the leading economists have developed various approaches in monitoring by stages: starting from a simplified approach which includes three stages (Hizatulin, 2012) to the most expanded approach, including monitoring in six (Doronina, 2006) and more stages. According to our belief, the assessment monitoring, motivation and stimulation of the enterprise personnel should be carried out in the following stages (Fig. 1):

1) justification of the objectives of the assessment monitoring, motivation and stimulation of personnel. Yes, objectives of the monitoring can be organizational with the purpose of identification of the communication processes stability among the enterprise employees, if necessary, to carry out the selection of personnel, its distribution, as well as to provide comfortable working conditions; economic - with the purpose of identifying reserves aimed at increasing profits of the enterprise; socio-psychological - in order to determine the guidelines for providing social protection and staffing, as well as improving psychological climate among employees of the enterprise. After identifying the objectives of the assessment monitoring, motivation and stimulation of personnel it is expedient to determine the types and frequency of its conduct. Yes, monitoring can be done both at the local level (incomplete study of the monitored object), and on the general (complex) (complete research of the monitored object); monitoring can be both onetime and periodic (collection and processing of information over a certain period of time) and progressive (collecting and processing information about the object for the purpose of monitoring, for the development of progressive measures aimed at improving the performance of personnel, its motivation and the effectiveness of stimulation systems); individual (studying personal needs of an employee, determining his level of motivation and analyzing his performance); internal (exploration of a certain department, shop or subdivision, analysis of the organizational structure, personnel policy, informal leadership in a team, etc.); external (level of employment, living standards of the population, their social needs, market segment infrastructure, etc.); 
2) selection of the implementation object and definition of job descriptions. Thus, the monitoring of the object of implementation can be carried out according to the professional composition of the employees - managers, specialists, employees, main and secondary workers; for units, divisions and workshops, departments and other subdivisions of the enterprise with the purpose of assessing the level of productivity and performance of personnel, group motivation and effectiveness of the group system of personnel stimulation of units, divisions, workshops, departments, etc. Definition of job responsibilities and establishment of planned labor standards for each employee.

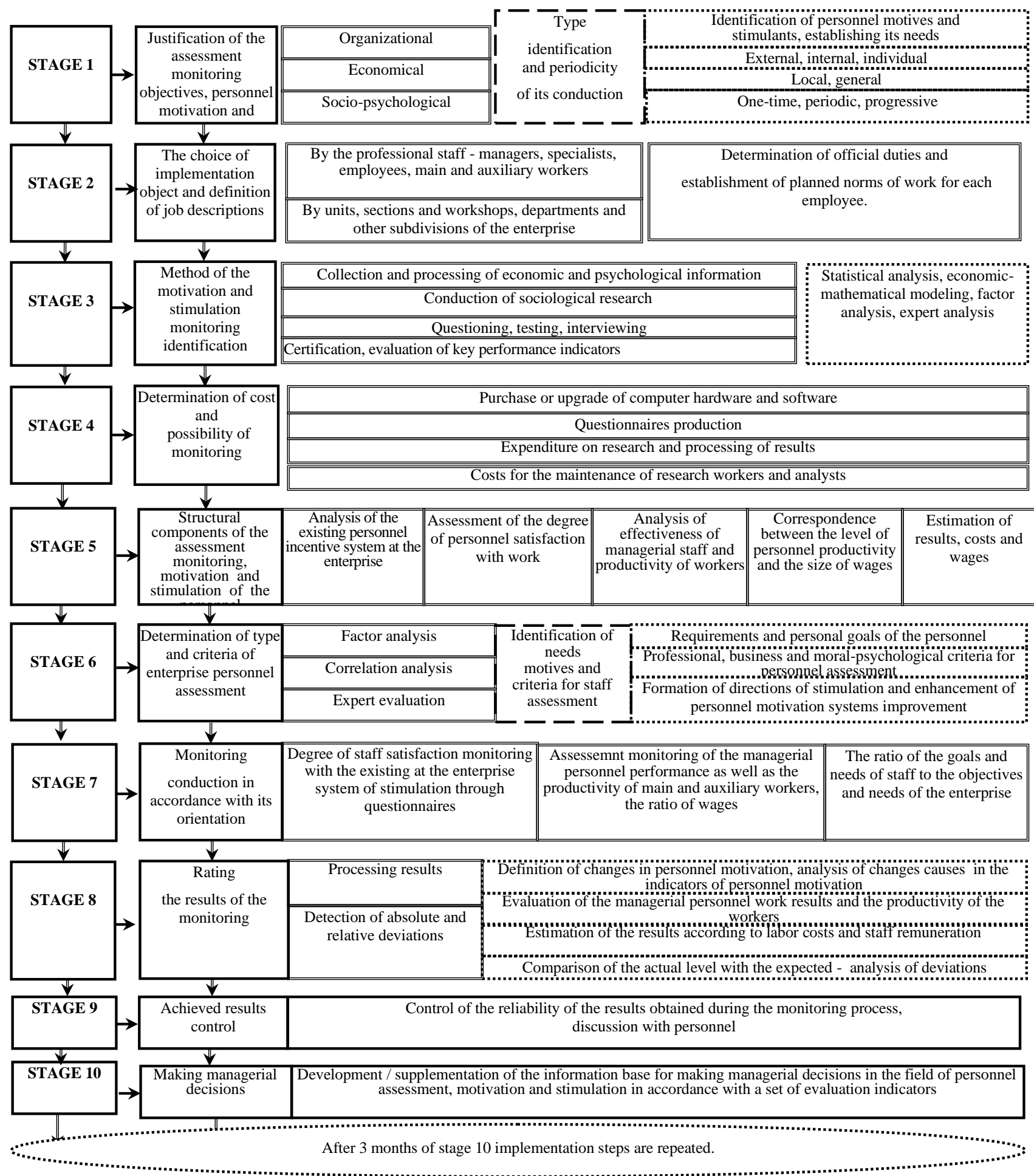

Figure 1. Stages of assessment monitoring, motivation and stimulation of machine-building enterprise personnel

* - developed by the author on the basis of his own research 
3) determination of the monitoring method takes place depending on the information collected. The collection of information may be based on questionnaires, testing, sociological surveys, interviews, etc.

Among the methods of personnel assessement, an enterprise can also use benchmarking of personnel, its certification, evaluation of individual employees, departments, workshops, polling stations, etc. based on key performance indicators, etc. When choosing a method of monitoring, it is important to take into account the strategy on which the company is oriented, as well as to identify its sectoral features. Therefore, when monitoring the assessment, motivation and stimulation of personnel it is expedient to use several methods simultaneously, or to develop on its basis strategic objectives of the enterprise and the peculiarities of its functioning, its own methodology for assessing, motivating and stimulating personnel of the machinebuilding enterprise, based on specific monitoring objectives, taking into account the specifics of the activity of one or another category of personnel, department, workshop, unit, etc.;

4) determining the value and feasibility of monitoring, which includes managers' expenditures for production of questionnaires, purchase or updating of computer equipment, software, salaries of analysts and researchers, the cost for research itself, and processing of results, etc.;

5) determination of structural components of monitoring, namely: establishing correspondence between the results of the personnel work and the level of its motivational orientation, between the size of wages and the level of productivity of the personnel; estimation of results of labor activity, expenses and wages;

6) the enterprise determines the type and criteria of personnel evaluation based on the specific needs, motives and personnel stimulation, and also on the basis of the existing structural components of the PAMSM;

7) monitoring in accordance with its focus determins the degree of personnel satisfaction with the existing incentive system at the enterprise, evaluation of employees performance and their correlation with the level of wages, identification and correlation of goals and needs of personnel with the objectives and needs of the enterprise. This stage determins the definition of effective directions for the development of the system of motivation and stimulation of personnel, individual goals and most urgent needs of personnel, their correspondence with the goals of the enterprise;

8) assessment of the monitoring results: reviewing results, identification of absolute and relative deviations. Assessment results are necessary in order to:

- formulate conclusions and generalizations as for the definition of changes in personnel motivation, efficiency and productivity of their work, labor costs and personnel payment, to analyze the reasons of changes;

- to establish and carry out analysis of the reasons for the deviations of the actual level of the obtained values from the expected indicators, standards, normative values;

- to identify the place occupied by a separate employee in a team or in a separate department, shop, division, etc. according to the labor activity performance, professionalism, certain achievements, skills and abilities;

- identify needs, motives, stimulants and demotivating factors that affect productivity and performance indicators of a single employee, department, workshop, division, unit or enterprise as a whole;

9) control of the results obtained includes monitoring the reliability of the results obtained during the monitoring process, discussions with the personnel. This stage ensures feedback of the previous stages with the personnel and is based on informing the staff on the results obtained in order to give them the opportunity to realize their existing problems and to increase the effectiveness of their labor activity;

10) development / supplementation of the information base for the adoption of managerial decisions in the field of evaluation, motivation and stimulation of personnel in accordance with the complex of evaluation indicators. This stage is based on the identification of ways to ensure effective formation and operation of the PAMSM based on the results of the monitoring.

Note that after a certain period of time, under the influence of one or another circumstance, there may be a change in personnel requirements: by satisfying some needs the worker forms priorities in satisfaction of others. In this regard, after 3 months of step 10 implementation steps are repeated.

Consequently, in the assessment monitoring, motivation and stimulation of the machine-building enterprise personnel, it is expedient to determine the needs of personnel, assess the qualitative and quantitative indicators of the work of personnel, distribution of personnel in accordance with the functions, establishment of his personal goals and provision of his social needs in accordance with the existing incentive system at the enterprise. Thus, the systematic review of the motivation needs of personnel, which is changing under the influence of personalized incentives, will be the basis for a combination of interests of managers and subordinates, which is just as possible to provide on the basis of such monitoring.

Thus, the main functions the assessment monitoring, motivation and stimulation provides for the personnel of the machine-building enterprise are the following: analysis and evaluation of personnel, personnel planning, organizational and management structures, improvement of the existing or change of the personnel stimulation system, implementation of managerial decisions to improve labor activity of the personnel, effectiveness of their performance, coordination and control of the results obtained in relation to the level of performance of the personnel, its motivation and effectiveness of the stimulation system.

Thus, organizational measures for the implementation of the assessment monitoring, motivation and stimulation of the machine-building enterprise personnel are based on the set of rules that are necessary for implementation:

1) necessity of psychological readiness of the top level manager (or one of the influential managers of other 
levels) at the enterprise prior to the introduction of monitoring, which is the key to its successful conduct;

2) it is desirable to implement monitoring gradually, starting from a separate category of employees or a separate department, shop, division, other subdivision, etc., and then make a consistent joining of other research objects;

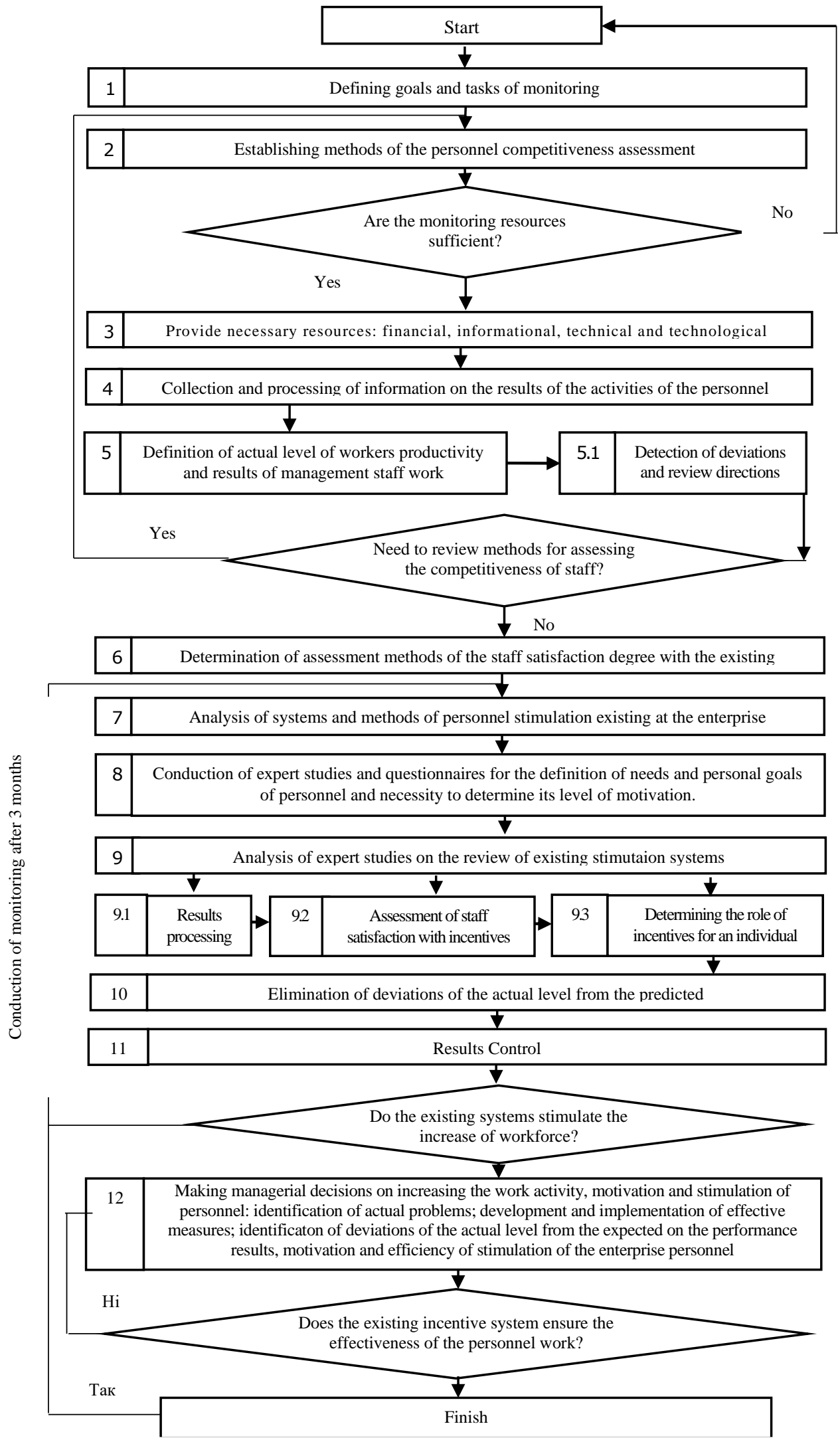

Figure 2. Algorithm for PAMSM

* - developed by the author on the basis of his own research 
3) conducting a methodical seminar at the enterprise, which is the premise of the successful launch of the assessment monitoring, motivation and stimulation of the machinebuilding enterprise personnel into operation. It is already possible during such a seminar to identify those who on a voluntary basis are included in the process of forming and ensuring the effective work of the PAMSM: whether it is a particular personnel category or a separate unit.

Algorithm for personnel's assessment, motivation and stimulation monitoring (PAMSM)

Consequently, based on the results of the research, practical solution of the tasks aimed at successful assessment monitoring, motivation and stimulation of the machine-building enterprise personnel and development of the effective PAMSM on this basis assumes the active involvement of creative and applied researches and developments of domestic and foreign scientists, as well as the acquisition of the experience of progressive enterprises, which are making significant progress in this area of activity. At present, the effective way of solving problems related to productivity growth, activization of labor activity, decrease in staff turnover, introduction of an effective system of personnel motivation and organization of its motivation is the transition from the motivating atmosphere at the enterprise to its regular evaluation, analysis of the stimulation system and development of effective measures aimed at its improvement. This is what the assessment monitoring, motivation and stimulation of the machinebuilding enterprises personnel is called to do, which will allow the relationship between the employer and the employee to be brought to a new, more advanced level.

Identification and formation of optimal measures, introduction of which is in the competence of the leader in order to influence specific motivational fact of an individual worker, or introduction of a set of measures aimed at meeting motivational needs of the main part of the personnel, appears to be a very difficult task. However, the proposed monitoring algorithm combined with the development and use of an incentives bulletin, which consists of brief information on a particular aspect of issues, namely the use of incentives to meet the motivational needs of the enterprise personnel, ensures successful implementation and operation of the PAMSM. The results of our research consist of the formation of the assessment monitoring, motivation and stimulaiton of the personnel at the machine-building enterprise on the basis of the structural scheme of its stages and algorithm for its implementation, with a systematic evaluation of its results regarding the adoption of managerial decisions aimed at the efficiency of personnel work, which provides by the feedback channels periodic assessment of personnel motivation level, the results of its work and the effectiveness of the existing motivation system at the enterprise, carried through the removal of actual indicators out of the normative.

At the same time for the system of motivation and stimulaton of personnel to be managed, it is unnecessary to create proper conditions: availability of full and correct information on the subject of management; necessity to have a constant indication of the state and dynamics of the personnel motivational orientation; a thorough examination of the socio-economic consequences of administrative decisions and the ability to prognosticate them. Therefore, conducting monitoring studies of motivation processes and personnel stimulation in the system of effective management of the enterprise enables to accumulate objective information in order to make informed management decisions for the purpose of its further use.

\section{Conclusions}

Consequently, the formed structural scheme of stages and algorithm of the assessment monitoring, motivation and stimulaton of the personnel can be defined as universal for any machine-building enterprise with different scale of production, number of personnel and performance results. The difference is only in the formed enterprise goals as for conducting monitoring and possibilities of the enterprise. The most expedient is the conduction frequency - once in a quarter, since during this period a restatement of the minimum wage is carried out.

Thus, the assessment monitoring, motivation and stimulation of the personnel will allow to obtain operational information on the condition and quality of labor processes at the machine-building enterprise, on the basis of which it is possible to effectively implement changes and adjustments to the directions and objectives of the activization of personnel performance, increase the level of motivation and improve the system of incentives.

\section{References}

1. Hizatulin, A. and Novikova O. (2012). Pecularities of development of the labor resources monitoring system at the enterprise. Social and economic problems and the state, 2, 146-154. [in Ukrainian].

2. Doronina, M. S., Naumik, E. G., Solovyev, O. V. (2006). Motivation management, Kharkov : Izd-vo KhNEU, 240 p. [in Ukrainian].

3. Goudge, P. (2006). Employee research: How to increase employee involvement through consultation, London : Kogan page, 272 p. [in Ukrainian].

4. Kniaz, O. V. (2006). Analysis and factors evaluation, which affect the level of innovation development of enterprises. Economy of industry, 36-43. [in Ukrainian].

5. Kolot, A. M. (2006). Personnel motivation, Kyiv : KNEU, 340 p. [in Ukrainian].

6. Krysin, L. P. (2007). Explanatory dictionary of foreign words, Moscow : EKSMO, 944 p. [in Ukrainian].

7. Lukashevych, M. P. (2004). Sociology of labor, Kyiv: Lybid, 2004. - 440 s. [in Ukrainian].

8. Parkhomchuk, O. (2001). Some limitations of performance results evaluation in collective management and their overcoming. Actual problems of state management, 3 (6), 80-85. [in Ukrainian].

9. $\quad$ Penc, J.(2001). Zarzadzania personelem w przedsiębiorstwie, Warszawa, $454 \mathrm{p}$.

10. Performance Appraisal Handbook (2010). U. S. Department of the Interior's performance management policy. Retrieved from http://www.doi.gov/hrm/guidance/370dm430hndbk.pdf. [in Ukrainian]. 